\title{
$\S 10$ Betrug in Ausübung eines Amtes, Art. 438 CP
}

Es stellt sich die Frage, wie das besonders enge Verhältnis zum Grundtatbestand systematisch einzuordnen ist. Zur Vorgängernorm, Art. 403 CP (a.F.), wurde diskutiert, ob diese eine Strafverschärfung darstellte oder ob in ihr ein Qualifikationstatbestand zu sehen war. Diese Zweifel sind auch für die neue Norm nicht zu beseitigen. Problematisch ist vor allem, daß mit Art. $22 \mathrm{Nr} .7 \mathrm{CP}$ ein ganz ähnlicher Inhalt als strafverschärfender Umstand gewertet wird ${ }^{1}$. Allerdings besteht Einigkeit darin, daß Art. $438 \mathrm{CP}$ die Anwendung des Art. $22 \mathrm{Nr} .7 \mathrm{CP}$ ausschließt ${ }^{2}$.

Über die Voraussetzungen der im Tatbestand genannten Delikte hinaus ist eine Amtseigenschaft i.S.d. Art. $24 \mathrm{CP}$ erforderlich ${ }^{3}$. Der Täter muß zur Begehung des Deliktes sein Amt mißbrauchen. Dazu ist erforderlich, daß er seine ihm übertragenen Kompetenzen in mißbräuchlicher Weise ausübt ${ }^{4}$. Soweit andere als Vermögensvorteile erstrebt werden, sind die Art. 437, 438, 443 und $444 \mathrm{CP}$ einschlägig 5 .

Hinsichtlich der deutschen Regelung ist darauf hinzuweisen, daß in $\S 263 \mathrm{Abs} .3$ S. 2, Nr. 4 StGB eine ganz ähnliche Norm existiert. Während Art. $438 \mathrm{CP}$ jedoch den Charakter einer Qualifikation hat, handelt es sich in $\S 263$ Abs. 3 S. 2, Nr. 4 StGB um eine Strafverschärfungsregelung.

l Der Tatbestand lautet: „Strafverschärfende Umstände sind: [...] Nr. 7. Das Ausnutzen der öffentlichen Stellung des Schuldigen. [...]."; der spanische Urtext lautet: „Son circunstancias agravantes: [...] 7. ${ }^{\circ}$ Prevalerse del cáracter público que tenga el culpable. [...]."

2 Morales Prats/Rodriguez Puerta in: Quintero Olivares, Comentarios, S. 1264; Orts Berenguer in: Vives Antón, Comentarios, S. 1865.

3 Art. 24.1 CP (Legaldefinition des Amtsträgers): „A los efectos penales se reputará autoridad al que por sí solo o como miembro de alguna corporación, tribunal u órgano colegiado tenga mando o ejerza jurisdicción propia. En todo caso, tendrán la consideración de autoridad los miembros del Congreso de los Diputados, del Senado, de las Asambleas Legislativas de las Comunidades Autónomas y del Parlamento Europeo. Se reputará también autoridad a los funcionarios del Ministerio Fiscal.“; Art. 24.2 CP (Legaldefinition des Beamten): „Se considerará funcionario público todo el que por disposición inmediata de la Ley o por elección o por nombramiento de autoridad competente participe en el ejercicio de funciones públicas."

4 STS 3.11.1993 [RJ 403].

5 Morales Prats/Rodríguez Puerta, in: Quintero Olivares, Comentarios, S. 1265. 